\title{
INDUCED RESISTANCE TO PERIWINKLE GRAZING IN THE BROWN SEAWEED FUCUS VESICULOSUS (PHAEOPHYCEAE): MOLECULAR INSIGHTS AND SEAWEED-MEDIATED EFFECTS ON HERBIVORE INTERACTIONS ${ }^{1}$
}

\author{
Carla R. Flöthe ${ }^{2}$ \\ Section Ecological Chemistry, Alfred-Wegener-Institut, Helmholtz-Zentrum für Polar- und Meeresforschung, Am Handelshafen 12, \\ Bremerhaven 27570, Germany \\ Markus Molis \\ Section Functional Ecology, Alfred-Wegener-Institut, Helmholtz-Zentrum für Polar- und Meeresforschung, Am Handelshafen 12, \\ Bremerhaven 27570, Germany \\ and Uwe John \\ Section Ecological Chemistry, Alfred-Wegener-Institut, Helmholtz-Zentrum für Polar- und Meeresforschung, Am Handelshafen 12, \\ Bremerhaven 27570, Germany
}

Herbivory is a key factor for controlling seaweed biomass and community structure. To cope with grazers, constitutive and inducible defenses have evolved in macroalgae. Inducible chemical defenses show grazer-specificity and, at the same time, have the potential to mediate interactions among different herbivores. Furthermore, temporal variations in defense patterns, which may adjust antiherbivory responses to grazing pressure, were reported in two brown seaweeds. However, underlying cellular processes are only rudimentarily characterized. To investigate the response of Fucus vesiculosus (L.) to periwinkle (Littorina obtusata) grazing, feeding assays were conducted at several times during a $33 \mathrm{~d}$ induction experiment. Underlying cellular processes were analyzed through gene expression profiling. Furthermore, direct processes driving the antiherbivory response to periwinkle grazing and indirect effects on another herbivore, the isopod Idotea baltica, were elucidated. $F$. vesiculosus showed multiple defense pulses in response to periwinkle grazing, suggesting a high level of temporal variability in antiherbivory traits. Defense induction was accompanied by extensive transcriptome changes. Approximately 400 genes were significantly up-/down-regulated relative to controls, including genes relevant for translation and the cytoskeleton. Genes involved in photosynthesis were mostly downregulated, while genes related to the respiratory chain were up-regulated, indicating alterations in resource allocation. The comparison of genes regulated in response to isopod (previous study) and periwinkle grazing suggests specific induction of several genes by each herbivore. However, grazing by both herbivores induced similar metabolic processes

\footnotetext{
${ }^{1}$ Received 16 December 2013. Accepted 20 March 2014.

${ }^{2}$ Author for correspondence: e-mail carla.floethe@awi.de

Editorial Responsibility: C. Amsler (Associate Editor)
}

in $F$. vesiculosus. These common defense-related processes reflected in strong indirect effects as isopods were also repelled after previous grazing by L. obtusata.

Key index words: feeding preference; gene expression; Idotea baltica; Littorina obtusata; microarray; phenotypic plasticity; seaweed-herbivore interaction; trait-mediated indirect interaction

Canopy-forming macroalgae are of great importance as bioengineers in rocky intertidal communities and support a complex food web by providing food, habitat, and protection to several other epiphytic and associated organisms (e.g., Golléty et al. 2010, Watt and Scrosati 2013). Seaweed-herbivore interactions have been shown to be an important structuring element in these coastal communities (Lubchenco and Gaines 1981, Gaines and Lubchenco 1982) because herbivores are able to remove considerable amounts of seaweed biomass (Poore et al. 2012).

Diverse traits have evolved in seaweeds to defend themselves against herbivory (Duffy and Hay 1990). These include traits that decrease seaweed attractiveness for herbivores, complicate seaweed ingestion by herbivores, and/or are toxic for herbivores (e.g., Pennings and Paul 1992, Augner 1995, Hay 1996). Antiherbivory defenses may be costly to produce and to maintain (Strauss et al. 2002). Thus, permanently expressed (= constitutive) defenses may be unnecessarily expensive when they are not always needed. Therefore, it can be advantageous for seaweeds to use defenses only on demand (= inducible defense), e.g., at times of high grazing pressure (e.g., Zangerl et al. 1997, Karban et al. 1999).

Potential costs of defense may be further reduced by temporal variation in inducible antiherbivory 
traits, e.g., by short-term defense pulses. Previous studies have shown, for instance, that continuous isopod grazing resulted in small-scale temporal variations in the palatability of two brown algal species, Ascophyllum nodosum and Fucus vesiculosus (Flöthe and Molis 2013, Flöthe et al. in press). Furthermore, inducible defenses do not only reduce seaweed susceptibility to herbivore attack but also have the potential to modify the feeding behavior of herbivores and competition among several herbivore species may be mediated by induced changes in seaweed traits (Long et al. 2007, Yun et al. 2010).

Although the ability of seaweeds to induce defenses in response to herbivory is well-established (Toth and Pavia 2007), molecular mechanisms underlying these complex responses have largely remained elusive. The brown alga $F$. vesiculosus was used to investigate several ecological (e.g., Hemmi et al. 2004, Rohde et al. 2004, Yun et al. 2010) and chemical (e.g., Geiselman and McConnell 1981, Deal et al. 2003, Kubanek et al. 2004) aspects of the induced antiherbivory defense and has recently become the focus of an initial genomic study (Flöthe et al. in press). Findings from studies on vascular plant defenses indicate that the response to grazing involves major shifts in gene expression of both, gene products that are directly involved in defensive plant responses and gene products without obvious deterrent functions (Cheong et al. 2002). Similar processes seem to be involved in the induction of antiherbivory defenses in $F$. vesiculosus by isopod grazing (Flöthe et al. in press). However, to elucidate general processes underlying defense induction in F. vesiculosus, more information about the response of this seaweed to different herbivore species is needed. Yet, it is unknown whether different herbivore species induce similar transcriptomic responses or whether $F$. vesiculosus expresses specific genes in response to different attacking herbivores. As the recognition of herbivore-specific cues may be an important mechanism for plants to optimize their defense responses to the inducing grazer species (Roda et al. 2004), it can be assumed that transcriptional changes elicited by herbivore grazing in F. vesiculosus show inducer-specific patterns. This may be especially true for herbivore species with different levels of specialization (Ali and Agrawal 2012) or salivary components (Coleman et al. 2007). On the contrary, there may be also a number of unspecific genes generally associated to the induction of antiherbivory defenses.

In this study, an already established model system the brown seaweed $F$. vesiculosus, the periwinkle Littorina obtusata, and the isopod Idotea baltica - was used in a time series experiment to address several questions. First, temporal variations in the chemical antiherbivory defense induced by continuous periwinkle grazing were investigated. Second, cellular processes underlying this induced defense were elucidated. Genes whose transcription changed early, late, tran- siently, or permanently during continuous periwinkle grazing were identified. Also differences in the gene expression between individual defense pulses were revealed. Third, periwinkle-induced processes were compared to those that underlie defense induction in response to isopod grazing (Flöthe et al. in press) to disclose universal as well as herbivore-specific processes. Fourth, as a certain degree of herbivore-specificity in the antiherbivory response was assumed, results of a previous study (Long et al. 2007) were validated to confirm the effect of a potential periwinkle-tailored defense on the isopod I. baltica.

\section{MATERIAL AND METHODS}

Study site. Organisms used in this study were collected during low tide in the mid rocky intertidal at Kringel, Helgoland, $\mathrm{NE}$ Atlantic $\left(54^{\circ} 10^{\prime} 60^{\prime \prime} \mathrm{N}, 7^{\circ} 53^{\prime} 15^{\prime \prime} \mathrm{E}\right)$ in June 2011. At Kringel, perennial canopy-forming brown seaweeds, in particular toothed wrack (Fucus serratus) and bladder wrack (F. vesiculosus), and the irish moss Mastocarpus stellatus dominate the intertidal. At the study site, the flat periwinkle (L. obtusata) is primarily associated with, and preferentially feeds on both Fucus species (Enge 2006, C. Flöthe, personal observation).

Experimental set-up and design. A feeding assay-based induction experiment assessed whether palatability of apical $F$. vesiculosus pieces varied during an induction and a reduction phase in response to direct grazing by the periwinkle L. obtusata. The experiment was run in a laboratory of the Biologische Anstalt Helgoland using a seawater flow-through system. Seawater was pumped from the nearby $(<50 \mathrm{~m})$ North Sea over a cotton filter into two $200 \mathrm{~L}$ tanks, from where transparent plastic aquaria ( $25 \mathrm{~L}$ volume; $480 \times 230 \times 260 \mathrm{~mm})$ were individually uni-directionally supplied at a mean $( \pm$ SD) flow rate of $464( \pm 87) \mathrm{mL} \cdot \mathrm{min}^{-1}$. To avoid animal escapes from the set-up, each aquarium was covered with a $3 \mathrm{~mm}$ thick transparent acrylic plate and each effluent pipe was covered with polystyrene mosquito mesh (mesh size $1.5 \mathrm{~mm}$ ). Two fluorescent tubes (Osram Lumilux Daylight L 36W/865) irradiated aquaria at a mean $( \pm \mathrm{SD})$ photon flow rate of 223 $( \pm 5) \mu \mathrm{mol}$ photons $\cdot \mathrm{m}^{-2} \cdot \mathrm{s}^{-1}$ (PAR) in a 12:12 $\mathrm{h}$ light-dark cycle. Average $( \pm \mathrm{SD})$ seawater temperature in aquaria was $18.1( \pm 0.5){ }^{\circ} \mathrm{C}$.

On June 3, 2011, 10 apical pieces lacking visual feeding scars were cut from 120 F. vesiculosus individuals. An algal individual was defined as the tissue stemming from a single holdfast. Within $30 \mathrm{~min}$ all algal pieces were transported to the laboratory, where macroscopic epibionts were gently removed with a soft sponge. To identify genetically identical $F$. vesiculosus pieces in the set-up, they were marked with colored threads. For each of 10 replicates, five pieces of each of 12 specimens were placed in a control aquarium, while the other five pieces of the same specimens were allocated to a treatment aquarium. This way, $12 \times 5(=60)$ seaweed pieces were placed in each aquarium (= 120 pieces per replicate $\times 10$ replicates $=1,200$ pieces in total). To prevent floating of $F$. vesiculosus pieces, they were separately anchored with cable ties (width $1.8 \mathrm{~mm}$ ) to a polyethylene mesh (mesh size $2 \mathrm{~mm}$ ) resting at the bottom of the aquaria.

Three sequential experimental phases were applied: acclimation, induction, and reduction. During acclimation, algal pieces remained in the set-up for $4 \mathrm{~d}$ without grazers to recover from experimental manipulations and to reduce putative induced defensive traits, which may have been attained by unknown grazing histories in the field. According to prior studies, $3 \mathrm{~d}$ are sufficiently long to reduce antiherbi- 
vory defenses in F. vesiculosus (e.g., Rohde and Wahl 2008). Subsequently, wet mass of $F$. vesiculosus pieces was determined by blotting them dry with paper towels for $20 \mathrm{~s}$ and weighing them to the nearest $0.001 \mathrm{~g}$ (Sartorius CPA323S; Sartorius, Göttingen, Germany). This was the standard procedure to measure wet mass of food items in this study.

On day 5 of the experiment, five genetically identical seaweed pieces were removed from each control and treatment aquarium of all replicates (Fig. 1). Two of the five pieces were transferred to feeding arenas with naïve grazers (= consumers, see subchapter "feeding assays" for details). To determine autogenic wet mass changes during feeding assays, a third piece was allocated to a feeding arena without consumers. A fourth piece was stored at $-80^{\circ} \mathrm{C}$ for max 4 weeks and used in feeding assays with artificial food pellets (see subchapter "reconstituted food" for details). The fifth and final $F$. vesiculosus piece was immediately shock frozen in liquid nitrogen, stored at $-80^{\circ} \mathrm{C}$ and used for gene expression analysis within the next 5 months. Treatment and corresponding control pieces originated from the same $F$. vesiculosus individual in the field to make sure that expression differences between both pieces were not due to interindividual variation. The same day the $27 \mathrm{~d}$ induction phase was started by adding 55 L. obtusata individuals (= inducers; $\geq 1 \mathrm{~cm}$ shell length) to each of the 10 treatment aquaria (now containing 55 seaweed pieces each), while grazers were absent from the remaining 10 aquaria $(=$ controls $)$. The treatment and control aquaria of each replicate were paired and pairs randomly arranged in the set-up. Every 3 d, five pieces

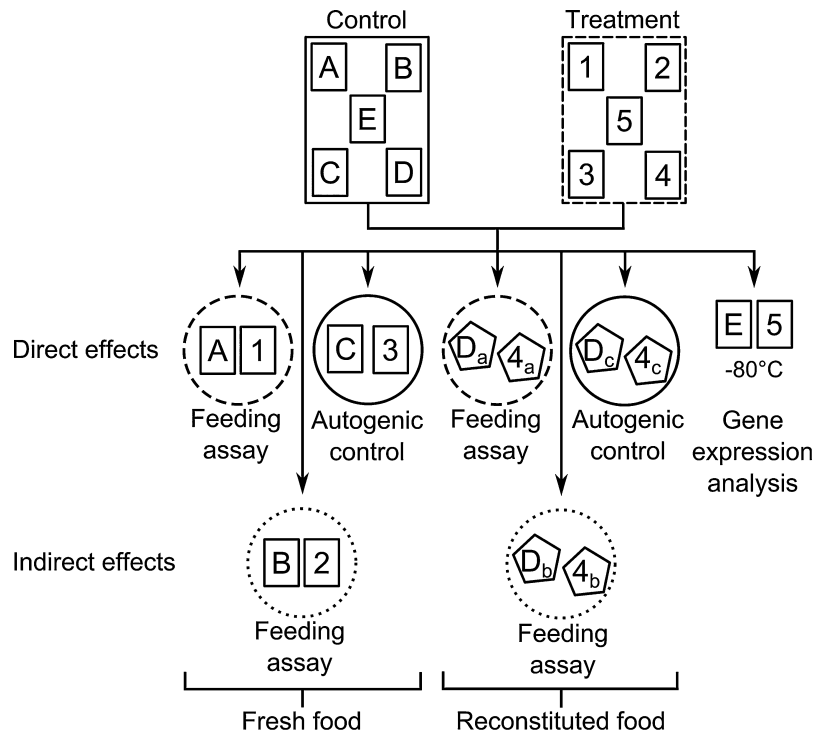

FIG. 1. Schematic illustration showing the allocation of Fucus vesiculosus pieces (small rectangles) for a single replicate at one of 12 sampling time points. Induction aquaria contained 60 pieces (only five shown) at the beginning of the experiment from which five were allocated to feeding arenas (circles) or gene expression analysis at each of the sampling times. Dashed and dotted lines indicate containers with Littorina obtusata (feeding assays testing for direct effects) and Idotea baltica (feeding assays testing for indirect effects), respectively. Solid lines indicate containers without grazers. Letters and numbers indicate ungrazed and grazer-exposed pieces of $F$. vesiculosus, respectively. Reconstituted food items (pentagons) used for feeding assays with $L . o b$ tusata (subscript a) and I. baltica (subscript b), and corresponding autogenic controls (subscript c) were derived from the same previously grazed or ungrazed seaweed piece. of $F$. vesiculosus were removed from all aquaria and allocated to feeding arenas or further processed as described above. Also, five periwinkles were removed from each treatment aquarium every $3 \mathrm{~d}$ to apply a comparable grazing pressure to residual $F$. vesiculosus pieces during the induction phase. The wet masses of $10 \mathrm{~F}$. vesiculosus pieces from each aquarium were measured at the start of the induction phase and every $3 \mathrm{~d}$ thereafter to monitor herbivore consumption during this experimental phase. The pieces were chosen randomly for each $3 \mathrm{~d}$ period and means were calculated from these 10 pieces as a replicate measure of consumption for statistical analysis.

To test whether potential induced antiherbivory traits are maintained after cessation of grazing, inducers were removed at the beginning of the reduction phase. Three and $6 \mathrm{~d}$ later, five pieces of $F$. vesiculosus were removed from all aquaria and allocated to feeding arenas or further processed as described for the induction phase.

Feeding assays. Fresh algae: Preference of herbivores for ungrazed or previously grazed $F$. vesiculosus was determined every $3 \mathrm{~d}$ in $72 \mathrm{~h}$ two-choice feeding assays throughout the induction and reduction phases. Plastic aquaria $(8 \mathrm{~L}$ volume; $325 \times 175 \times 185 \mathrm{~mm}$ ) were used as feeding arenas, in which 10 L. obtusata or one male I. baltica (= consumers) could choose between a previously grazed and a nongrazed piece of genetically identical $F$. vesiculosus. To test for direct and indirect effects mediated by $F$. vesiculosus, both the same and different species of inducer and consumer were used. Naïve consumers, which were not in contact with $F$. vesiculosus during the induction phase, were used in feeding assays to avoid grazer adaptations. Wet mass of $F$. vesiculosus pieces in feeding arenas (= assayed alga) was measured at the beginning and end of feeding assays. To correct consumption rates for nonfeeding related (autogenic) changes in the wet mass of an assayed alga, a second $F$. vesiculosus piece was withdrawn from the same aquarium from which the assayed alga originated (i.e., assayed alga and its autogenic control had comparable grazing histories during the experiment) and allocated to a feeding arena without consumers. By using the same number of autogenic controls and assayed algae, the risk of underestimating error variance of autogenic controls, and thus of committing a type I error, was reduced (Roa 1992). Consumption of each assayed algal piece was then calculated according to the following formula (adopted from Cronin and Hay 1996):

$$
\text { consumption }=\mathrm{T}_{\text {start }} \times\left(\mathrm{C}_{\text {end }} / \mathrm{C}_{\text {start }}\right)-\mathrm{T}_{\text {end }}
$$

where $T_{\text {start }}$ and $T_{\text {end }}$ represent the wet mass of an assayed algal piece before and after the feeding assay, respectively, and $\mathrm{C}_{\mathrm{start}}$ and $\mathrm{C}_{\text {end }}$ represent pre- and post-feeding assay wet mass of the corresponding autogenic control alga, respectively.

Reconstituted food: To determine whether induced changes in palatability were due to chemical, rather than morphological grazer-deterrent traits, additional feeding assays with reconstituted food were conducted. F. vesiculosus pieces that were stored at $-80^{\circ} \mathrm{C}$ were used for the preparation of reconstituted food. Frozen pieces were freeze-dried for $24 \mathrm{~h}$ at $-30^{\circ} \mathrm{C}$ and 0.37 mbar (Christ Beta 1-8 LD plus; Martin Christ Gefriertrocknungsanlagen, Osterode am Harz, Germany) before they were ground to a homogenous powder with a mixer mill (Schwingmühle MM 400; Retsch Laborgeräte, Haan, Germany) for $10 \mathrm{~s}$ at a frequency of $25 \mathrm{~Hz}$. Afterwards, $0.4 \mathrm{~g}$ of this algal powder were mixed with $3.6 \mathrm{~mL}$ of molten agar (a blend of $0.02 \mathrm{~g}$ agar per $\mathrm{mL}$ of boiling distilled water) after agar had cooled to $45^{\circ} \mathrm{C}$ to minimize any thermal destruction of bioactive chemical seaweed compounds. Subsequently, this alloy was poured on a mosquito mesh (mesh size $1.5 \mathrm{~mm}$ ) and flattened 
between two PVC panels coated with wax paper (method adopted from Hay et al. 1994). A $1 \mathrm{~mm}$ thick plastic template placed between both PVC panels generated reconstituted food pellets of uniform thickness. After solidification, three food items of $1.5 \times 1.5 \mathrm{~cm}$ area were cut from each pellet. One food item was used in a two-choice feeding assay with L. obtusata, while the second one was used in a feeding assay with I. baltica. The third food item was used as an autogenic control. Each of the three food items was placed in a glass Petri dish $(\varnothing$ $10 \mathrm{~cm}, 2 \mathrm{~cm}$ height) and transferred to a separate feeding arena (specifications see section "fresh algae"). Each feeding arena contained one Petri dish with a food item made from a previously grazed $F$. vesiculosus piece and a second Petri dish with a food item made from an ungrazed piece of $F$. vesiculosus. Placing food items in Petri dishes within feeding arenas permitted correct allocation of fragments, which occasionally broke off by grazer activities, to original food items. Both food items in a feeding arena were weighed at the beginning of a feeding assay and consumers $(10 \mathrm{~L}$. obtusata or one male I. baltica) were added. Feeding arenas which assessed autogenic wet mass changes remained without consumers. Feeding assays were terminated and wet mass of food items measured again after $3 \mathrm{~d}$ or when $\geq 50 \%$ of one food item was consumed, whichever occurred first.

RNA extraction and microarray hybridizations: Results from feeding assays suggested a strong decline in $F$. vesiculosus palatability from day 12 to 15 and again from day 21 to 24 . Therefore, expression patterns of seaweed genes were examined at the following points in time: shortly after the beginning of grazing to include the initial response to grazing (day 3), as well as shortly before (day 12 and day 21) and while (day 15 and day 24 ) ungrazed control $F$. vesiculosus pieces were significantly preferred over previously grazed pieces in feeding assays. Grazinginduced differentially expressed genes were identified by comparing ungrazed control $F$. vesiculosus pieces with grazed pieces at the given time points. Thus, total RNA of grazed as well as of ungrazed $F$. vesiculosus pieces collected at the abovementioned times was extracted and hybridized against pooled RNA from five $F$. vesiculosus individuals that were collected at day 0 .

Frozen pieces of $F$. vesiculosus were ground with mortar and pestle in liquid nitrogen and transferred to $2.0 \mathrm{~mL}$ tubes (Eppendorf, Hamburg, Germany). For isolation of total RNA $1 \mathrm{~mL}$ extraction buffer (2\% CTAB, $1 \mathrm{M} \mathrm{NaCl}, 100 \mathrm{mM}$ Tris $\mathrm{pH} 8,50 \mathrm{mM}$ EDTA $\mathrm{pH} 8$; adapted from Heinrich et al. 2012) and $25 \mu \mathrm{L}$ DTT $2 \mathrm{M}$ were added to the ground tissue and mixed using a vortex mixer. After incubation at $45^{\circ} \mathrm{C}$ for $15 \mathrm{~min}$ two consecutive chloroform extractions were performed (method adopted from Pearson et al. 2006). Subsequently, total RNA was extracted using the RNeasy Plant Mini Kit (Qiagen, Hildesheim, Germany) according to the manufacturer's protocol including on-column DNA digestion. RNA quantity and quality were determined using a NanoDrop ND1000 spectrophotometer (PeqLab Biotechnologie, Erlangen, Germany). RNA integrity was verified with the 2100 Bioanalyzer (Agilent Technologies, Palo Alto, CA, USA) using a RNA 6000 Nano Chip.

The Agilent Two-Color Low input Quick Amp Labeling Kit was used for amplification, reverse transcription, and labeling of $200 \mathrm{ng}$ of total RNA according to the manufacturer's protocol. RNA Spike-In Mix was added to RNA samples prior to labeling to serve as internal standard and benchmark for hybridization performance. RNA from seaweed pieces that were collected at day 0 was labeled with cyanine-5 (Cy5), while RNA isolated from control and previously grazed $F$. vesiculosus pieces from all other time points was labeled with cyanine-3 (Cy3). Due to the presence of long $3^{\prime}$ UTR sequences in brown seaweed, random hexamers with attached T7 promotor were added as a minor modification (Apt et al. 1995). Subsequently, cRNA concentration and dye incorporation rates were determined using the NanoDrop ND-1000 spectrophotometer (PeqLab Biotechnologie, Erlangen, Germany). Hybridizations were carried out in five biological replicates onto $4 \times 44 \mathrm{~K}$ microarray slides, which were designed with the Agilent eArray platform, using the Agilent Gene Expression Hybridization Kit according to the manufacturer's protocol. Slides contained oligonucleotide 60mers designed from a $F$. vesiculosus cDNA library containing transcripts of grazed $F$. vesiculosus (data available on request). Thereby, 24,927 transcripts were represented by either one or two individual probes. Microarray slides were placed in Agilent SureHyb hybridization chambers and incubated for $17 \mathrm{~h}$ at $65^{\circ} \mathrm{C}$ in an Agilent Microarray Hybridization Oven. Microarray disassembly and washing was performed according to the manufacturer's instructions and slides were scanned with the Agilent G2565AA Microarray Scanner system at $5 \mu \mathrm{m}$ resolution.

Statistical analyses. Fucus vesiculosus palatability: Periwinkle consumption rate during $3 \mathrm{~d}$ intervals in the induction phase was analyzed by resampling without replacement, using a Monte Carlo analysis with 10,000 permutations (Bärlocher 1999).

A repeated measures analysis of variance (RM-ANOVA) was used to test for the effects of L. obtusata grazing (within-subject measure: two levels, fixed) on the palatability of $F$. vesiculosus pieces for both consumer species (between-subject measure: two levels, fixed) at different times of the induction phase (between-subject measures: nine levels, fixed) and reduction phase (between-subject measures: two levels, fixed). As the within-subject factor had only two levels, testing for sphericity is not applicable (Quinn and Keough 2002). Due to experimental confirmation that L. obtusata induces antiherbivory defenses in F. vesiculosus (Long et al. 2007), onetailed paired $t$-tests were performed as post-hoc tests. To reveal which combination of treatments caused significant interactions, $t$-tests were performed separately for each time point. Prior to statistical analyses, normal distribution of differences between ungrazed and previously grazed seaweed pieces was confirmed using the Kolmogorov-Smirnov test. As the probability of finding the number of significant $t$-tests by chance was always $\leq 5 \%$, no Bonferroni correction was calculated (Moran 2003).

Microarray hybridizations: Microarray raw data extraction from scanned images and LOWESS (locally weighted scatterplot smoothing) normalization were carried out with the Agilent Feature Extraction Software (version 10.7.31). For monitoring array quality the Agilent QC Tool with the metric set GE2_QCMT_Feb07 was used. LOWESS normalized expression values were analyzed with the Agilent GeneSpring GX software (Version 11) to identify genes differentially regulated relative to day 0 . Average intensity values across replicates were used for statistical analysis by two-way ANOVA with treatment (two levels, fixed) and time (three levels, fixed) as main factors. An ANOVA $P$-value of 0.01 was chosen to indicate statistical significance. Subsequently, fold change analysis with a cut-off of 1.5 was performed on genes that were found to be differentially expressed from the statistical analysis. Thereby, the option "pairs of conditions" was used to perform pairwise comparisons of microarray data from two conditions (e.g., control vs. treatment at each time point). A 1.5fold cut-off was chosen to avoid underestimation of the extent of up- or down-regulation since also a minute change in the transcriptional abundance (e.g., of a transcription factor) could lead to a considerable biological effect (Reymond et al. 2004). Afterwards, expression values of controls (e.g., control day 3 vs. day 0) were subtracted from corresponding treatment values (e.g., treatment day 3 vs. day 0 ) at each time point to obtain only grazing-related changes in gene expression. 
Statistically significant genes were annotated by sequence comparisons using NCBI sequence database, Swiss-Prot protein knowledgebase, Clusters of eukaryotic orthologous groups (KOG), and Pfam protein families database with an evalue cut-off of $10^{-7}$. Microarray data have been deposited in the NCBI Gene Expression Omnibus and are accessible through GEO Series accession number GSE 53262 (http:// www.ncbi.nlm.nih.gov/geo/query/acc.cgi?acc=GSE53262).

\section{RESULTS}

Fucus vesiculosus palatability. All F. vesiculosus pieces exposed to inducers during induction phase showed visual grazing damage. Average grazer consumption during induction phase was $2.3 \%$ of initial wet weight. Consumption of $F$. vesiculosus by L. obtusata was not significantly different during the induction phase (resampling: $P=0.726$; Fig. 2).

Feeding assays. Direct effects: At the end of the acclimation phase, L. obtusata consumed equal amounts of $F$. vesiculosus pieces from designated control and treatment aquaria in assays using fresh algae (one-tailed paired $t$-test: $t_{9}=-0.33, P=0.375$ ) as well as in feeding assays using reconstituted food (one-tailed paired $t$-test: $t_{9}=-0.14, P=0.448$ ).

During induction phase, L. obtusata significantly preferred control pieces over previously grazed pieces in both fresh and reconstituted food assays (Table 1). The amount of seaweed biomass consumed by L. obtusata varied with time and there was a significant interaction between treatment and time in fresh food feeding assays. Previously nongrazed fresh $F$. vesiculosus pieces were significantly more consumed than L. obtusata grazed pieces in the feeding assays conducted after 15, 24 and $27 \mathrm{~d}$ of grazing in the induction phase (Table 2). During reduction phase, L. obtusata continued to significantly prefer fresh control pieces over previously grazed pieces 3 , but not $6 \mathrm{~d}$ after grazing had ceased (Table 2; Fig. 3A).

Similarly, L. obtusata consumed significantly more reconstituted food made from previously ungrazed

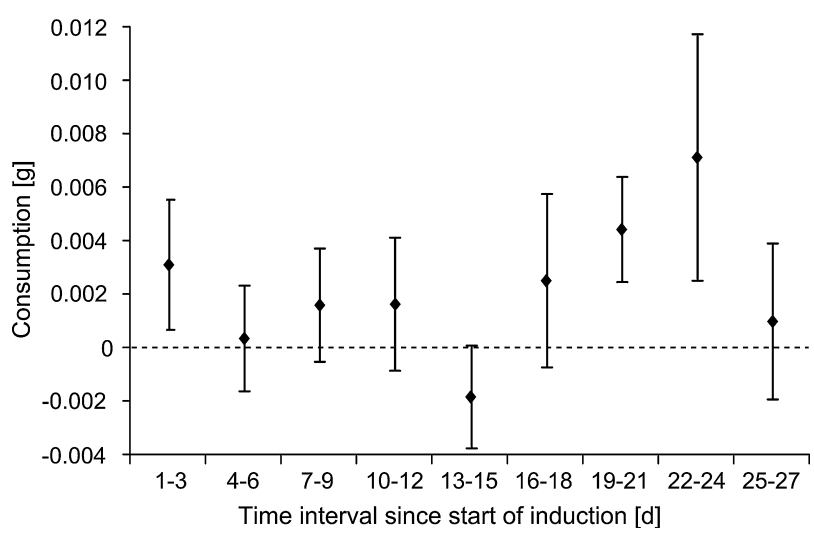

FIG. 2. Consumption of Fucus vesiculosus by Littorina obtusata during $3 \mathrm{~d}$ intervals in the induction phase. Data are shown as mean $\pm \operatorname{SE}(n=10)$.
F. vesiculosus than reconstituted food made from $F$. vesiculosus pieces that were grazed in the induction phase by L. obtusata for 15, 18, and $27 \mathrm{~d}$. In the reduction phase, controls were also significantly preferred over previously grazed $F$. vesiculosus pieces 3 , but not $6 \mathrm{~d}$ after grazers were removed from aquaria (Table 2; Fig. 3C).

Indirect effects: I. baltica consumed equal amounts of $F$. vesiculosus pieces from designated control and treatment aquaria in assays using fresh algae (onetailed paired $t$-test: $\left.t_{9}=-0.69, P=0.253\right)$ as well as in feeding assays using reconstituted food (onetailed paired $t$-test: $\left.t_{9}=0.56, P=0.296\right)$ directly after the acclimation phase.

During induction and reduction phase, I. baltica consumed significantly more of fresh $F$. vesiculosus than L. obtusata in feeding assays (Table 1). Nevertheless, isopods also significantly preferred control pieces over previously grazed pieces in both fresh and reconstituted food assays. This preference was dependent on the time of previous grazing. Ungrazed fresh pieces of $F$. vesiculosus were significantly more consumed by I. baltica than pieces that were previously grazed for 9, 15, 21, 24, and $27 \mathrm{~d}$ by L. obtusata (Table 2, Fig. 3B).

In the reconstituted food assays, I. baltica significantly preferred food made from previously ungrazed F. vesiculosus over food made from $F$. vesiculosus pieces that were grazed in the induction phase by L. obtusata for 15, 21, and $27 \mathrm{~d}$ (Table 2, Fig. 3D).

There were no significant differences in the consumption of previously grazed and nongrazed $F$. vesiculosus pieces during the reduction phase in both, assays with fresh seaweed pieces and reconstituted food (Table 2).

Gene expression analysis: Microarray analyses demonstrated differential gene expression in F. vesiculosus grazed by L. obtusata compared to the corresponding control pieces. A total of 426 individual genes were differentially expressed in seaweed pieces that were previously grazed for 3, 12, 15, 21, and $24 \mathrm{~d}$ compared to controls. The number of up/ down regulated genes stayed nearly constant at the d 3, 12, and $15(61 / 124,66 / 115$ and 46/195, respectively), then increased to $119 / 151$ (day 21), and finally decreased to $88 / 99$ (day 24). Fifty-five genes were commonly expressed at all points in time (Fig. S1 in the Supporting Information), whereas 42, 24, 37, 40, and 14 genes were uniquely regulated 3, 12, 15, 21, and $24 \mathrm{~d}$ after the start of the induction phase, respectively. Altogether about $30 \%$ of all regulated genes were functionally annotated (Table S1 in the Supporting Information) and assigned to $\mathrm{KOG}$ categories giving insights in their function.

Patterns after $3 d$ of grazing: Most genes that were up-regulated after $3 \mathrm{~d}$ of L. obtusata grazing could not be assigned to any KOG category since there was no functional annotation data available. One 
TABLE 1. Results of the three-factorial RM-ANOVA for the induction and reduction phase, comparing feeding rates affected by treatment (ungrazed/grazed), consumer species (Littorina obtusata/Idotea baltica), and time. Consumption was assessed in two-choice feeding assays using either fresh or reconstituted Fucus vesiculosus $(n=10$, except for the reconstituted food feeding assays conducted $12 \mathrm{~d}$ after start of induction with both I. baltica and L. obtusata, where one replicate was lost in each case). Significant $P$-values (i.e., $\alpha \leq 0.05$ ) in bold.

\begin{tabular}{|c|c|c|c|c|c|c|c|c|}
\hline & \multicolumn{4}{|c|}{ Fresh food } & \multicolumn{4}{|c|}{ Reconstituted food } \\
\hline & df & MS & $F$ & $P$ & df & MS & F & $P$ \\
\hline \multicolumn{9}{|l|}{ Induction phase } \\
\hline Time & 8 & 0.004 & 2.10 & 0.039 & 8 & 0.028 & 2.33 & 0.022 \\
\hline Consumer & 1 & 0.173 & 87.99 & $<0.001$ & 1 & 0.281 & 23.45 & $<0.001$ \\
\hline Time $\times$ Consumer & 8 & 0.001 & 0.62 & 0.760 & 8 & 0.026 & 2.15 & 0.034 \\
\hline Error & 162 & 0.002 & & & 160 & 0.012 & & \\
\hline Treatment & 1 & 0.048 & 34.44 & $<0.001$ & 1 & 0.091 & 7.23 & 0.008 \\
\hline Treatment $\times$ Time & 8 & 0.004 & 3.06 & 0.003 & 8 & 0.021 & 1.64 & 0.118 \\
\hline Treatment $\times$ Consumer & 1 & 0.009 & 6.50 & 0.012 & 1 & $3.94 \times 10^{-4}$ & 0.03 & 0.859 \\
\hline Treatment $\times$ Time $\times$ Consumer & 8 & 0.002 & 1.35 & 0.222 & 8 & 0.006 & 0.51 & 0.848 \\
\hline Error & 162 & 0.001 & & & 160 & 0.013 & & \\
\hline \multicolumn{9}{|l|}{ Reduction phase } \\
\hline Time & 1 & $7.12 \times 10^{-4}$ & 0.32 & 0.575 & 1 & 0.006 & 0.41 & 0.525 \\
\hline Consumer & 1 & 0.009 & 4.07 & 0.051 & 1 & 0.116 & 7.74 & 0.009 \\
\hline Time $\times$ Consumer & 1 & 0.003 & 1.24 & 0.273 & 1 & 0.031 & 2.08 & 0.158 \\
\hline Error & 36 & 0.002 & & & 36 & 0.015 & & \\
\hline Treatment & 1 & 0.005 & 4.65 & 0.038 & 1 & 0.001 & 0.11 & 0.743 \\
\hline Treatment $\times$ Time & 1 & 0.001 & 1.15 & 0.291 & 1 & 0.011 & 0.91 & 0.345 \\
\hline Treatment $\times$ Consumer & 1 & $2.09 \times 10^{-5}$ & 0.02 & 0.888 & 1 & 0.015 & 1.25 & 0.270 \\
\hline Treatment $\times$ Time $\times$ Consumer & 1 & $2.73 \times 10^{-4}$ & 0.26 & 0.612 & 1 & $5.11 \times 10^{-6}$ & $<0.01$ & 0.984 \\
\hline Error & 36 & 0.001 & & & 36 & 0.012 & & \\
\hline
\end{tabular}

TABLE 2. Results of one-tailed paired $t$-tests comparing controls and previously grazed seaweed pieces. Consumption of Littorina obtusata and Idotea baltica was assessed in feeding assays using either fresh or reconstituted food pieces of Fucus vesiculosus ( $n=10$, except for the reconstituted food feeding assays conducted $12 \mathrm{~d}$ after start of induction with both $I$. baltica and L. obtusata, where one replicate was lost in each case). Time $=\mathrm{d}$ after start the of the induction phase. Day $0-$ 27 = induction phase. Day $30-33=$ reduction phase. Significant $P$-values (i.e., $\alpha \leq 0.05$ ) in bold.

\begin{tabular}{|c|c|c|c|c|c|c|c|c|}
\hline \multirow[b]{3}{*}{ Time [d] } & \multicolumn{4}{|c|}{ L. obtusata } & \multicolumn{4}{|c|}{ I. baltica } \\
\hline & \multicolumn{2}{|c|}{ Fresh algae } & \multicolumn{2}{|c|}{ Reconstituted food } & \multicolumn{2}{|c|}{ Fresh algae } & \multicolumn{2}{|c|}{ Reconstituted food } \\
\hline & $t$ & $P$ & $t$ & $P$ & $t$ & $P$ & $t$ & $P$ \\
\hline 3 & -1.01 & 0.170 & 0.11 & 0.456 & -0.58 & 0.287 & -0.05 & 0.479 \\
\hline 6 & 0.65 & 0.265 & -0.16 & 0.439 & 0.35 & 0.369 & 1.13 & 0.144 \\
\hline 9 & 0.89 & 0.199 & 0.25 & 0.404 & 4.42 & 0.001 & -0.45 & 0.332 \\
\hline 12 & 0.74 & 0.240 & 0.76 & 0.235 & -0.92 & 0.190 & -0.03 & 0.489 \\
\hline 15 & 1.99 & 0.039 & 1.98 & 0.040 & 1.94 & 0.042 & 1.10 & 0.039 \\
\hline 18 & 1.35 & 0.105 & 2.73 & 0.012 & 1.61 & 0.071 & -0.19 & 0.427 \\
\hline 21 & 0.82 & 0.216 & 0.20 & 0.422 & 2.75 & 0.011 & -0.33 & 0.375 \\
\hline 24 & 1.93 & 0.043 & 0.42 & 0.342 & 2.47 & 0.018 & 1.87 & 0.047 \\
\hline 27 & 3.92 & 0.002 & 2.66 & 0.013 & 2.56 & 0.015 & 2.27 & 0.025 \\
\hline 30 & 2.16 & 0.029 & 1.92 & 0.043 & 1.37 & 0.101 & 0.06 & 0.477 \\
\hline 33 & 0.74 & 0.241 & 0.43 & 0.339 & 0.50 & 0.313 & -1.05 & 0.162 \\
\hline
\end{tabular}

gene encoding for a ribosomal protein was assigned to the category "Translation, ribosomal structure and biogenesis" and one gene encoding for the beta chain of tubulin was assigned to the category "Cytoskeleton" (Table S1).

Genes that were down-regulated $3 \mathrm{~d}$ after the start of the induction phase included genes belonging to the KOG categories "Energy production and conversion," "Translation, ribosomal structure and biogenesis," and "Cytoskeleton." Downregulated genes related to translation primarily encoded for ribosomal proteins. The category "Energy production and conversion" was almost exclusively comprised of genes involved in photosynthesis (e.g., D2 reaction center protein of photosystem II, fucoxanthin-chl $a-c$ binding protein, photosystem II $4 \mathrm{kDa}$ reaction centre component, and oxygen-evolving enhancer protein 3). Within the category "Cytoskeleton," genes encoding for actin and the F-actin-capping protein subunit beta were found (Table S1).

Patterns after $12 d$ of grazing: Most of the genes that were up-regulated in $F$. vesiculosus $12 \mathrm{~d}$ after the start of the induction phase could be assigned to the KOG categories "Cytoskeleton," "Translation," and "Chromatin structure and dynamics." 
Direct effects
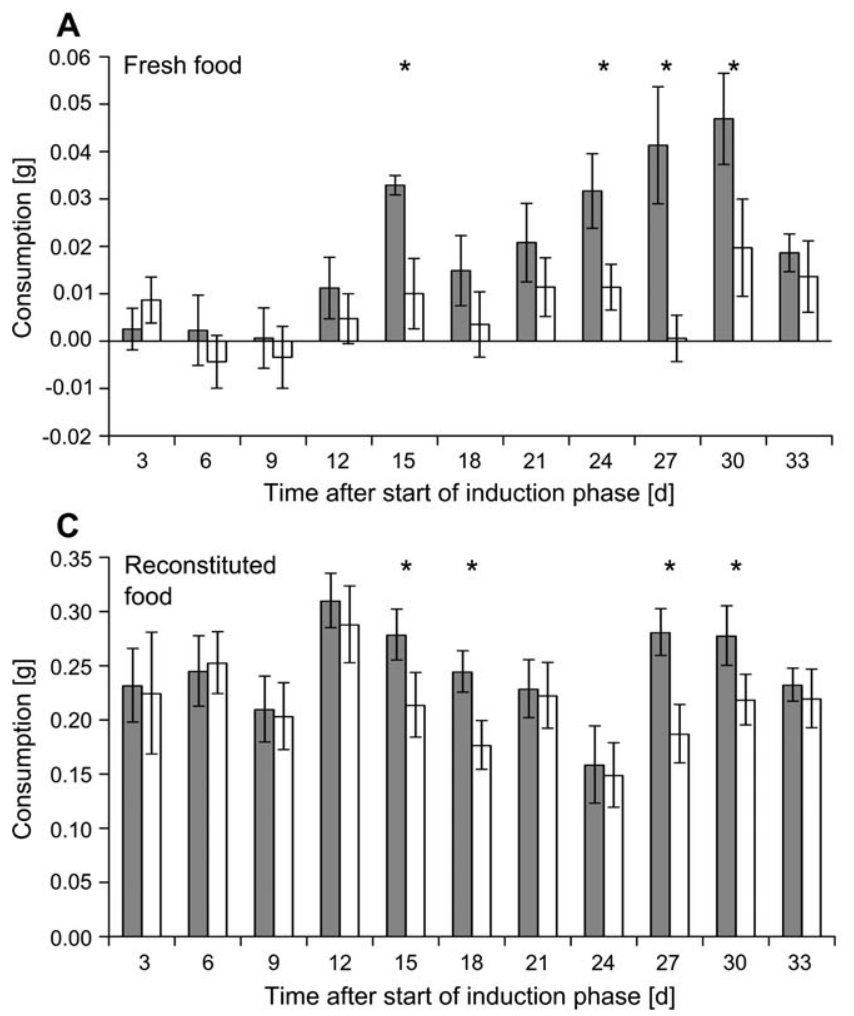

Indirect effects
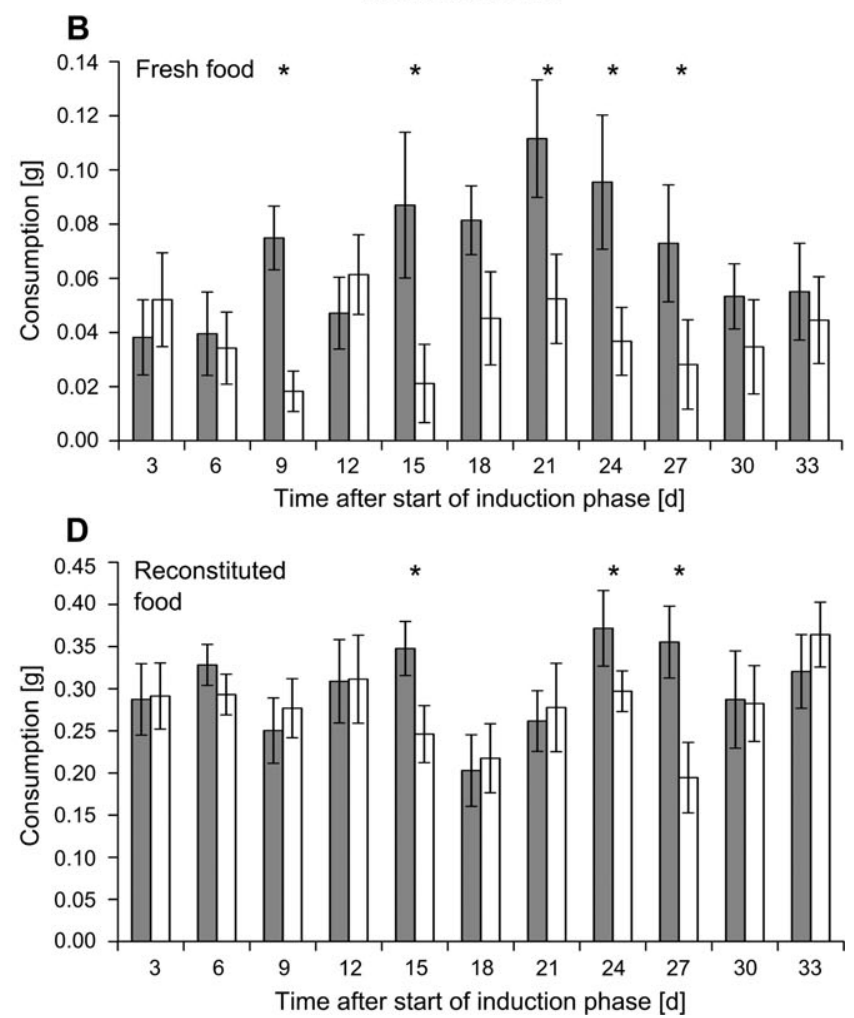

FIG. 3. Mean \pm SE consumption of fresh (A) and reconstituted (C) Fucus vesiculosus pieces by the periwinkle Littorina obtusata (= direct effects) and fresh (B) and reconstituted (D) F. vesiculosus pieces by the isopod Idotea baltica (= indirect effects) in two-choice feeding assays during induction (day 3-27) and reduction (days 30 and 33) phase. $n=10$, except for day 12 when one replicate was lost in reconstituted food feeding assays conducted with L. obtusata and I. baltica. Grey bars $=F$. vesiculosus pieces without previous exposure to grazing (controls); open bars = previously grazed seaweed pieces. Asterisks indicate significant differences based on results of one-tailed paired $t$-tests comparing distribution of differences between control and grazed pieces against the null-hypothesis of no difference.

Up-regulated genes related to the cytoskeleton encoded actin, cofilin, gelsolin, and profilin. Genes involved in translation encoded ribosomal proteins, while genes relevant for chromatin structure encoded histones (Table S1).

Genes that were down-regulated $12 \mathrm{~d}$ after the onset of grazing included genes belonging to the categories "Translation, ribosomal structure and biogenesis," "Cytoskeleton," and "Energy production and conversion." Genes belonging to the category "Translation, ribosomal structure and biogenesis" encoded ribosomal proteins, which were different from the up-regulated genes assigned to this category. Genes related to the cytoskeleton encoded actin, the tubulin $\beta$-chain, and the F-actin-capping protein subunit beta. The category "Energy production and conversion" contained only photosynthesisrelated genes (e.g., P700 apoprotein A1 of Photosystem I, fucoxanthin-chl $a-c$ binding protein, oxygen-evolving enhancer protein 3; Table S1).

Patterns after $15 d$ of grazing: Sixty-three per cent of all annotated genes that were up-regulated after $15 \mathrm{~d}$ of grazing were assigned to the category "Energy production and conversion." A number of these genes encoded for proteins related to photosynthesis (e.g., fucoxanthin chl $a / c$ binding protein), while few genes encoded proteins involved in the respiratory chain (e.g., cytochrome c and NADH-ubiquinone oxidoreductase; Table S1).

Most genes down-regulated in $F$. vesiculosus $15 \mathrm{~d}$ after onset of grazing were allocated to the KOG categories "Translation, ribosomal structure and biogenesis," "Cytoskeleton," and "Energy production and conversion." Genes assigned to the category "Translation, ribosomal structure and biogenesis" mostly encoded ribosomal proteins. The category "Cytoskeleton" was comprised of genes coding for actin, gelsolin, tropomyosin, and coactosin. Genes belonging to the category "Energy production and conversion" included various genes encoding photosynthesis-related proteins, such as oxygen-evolving enhancer protein 3, D2 reaction center protein of photosystem II, photosystem II $4 \mathrm{kDa}$ reaction centre component, and fucoxanthin-chl $a-c$ binding protein, as well as for the large subunit of ribulose1,5-bisphosphate carboxylase/oxygenase (Table S1).

Patterns after $21 d$ of grazing: Most genes that were up-regulated $21 \mathrm{~d}$ after the onset of L. obtusata 
grazing were assigned to the following KOG categories: "Energy production and conversion," "Cytoskeleton," "Translation, ribosomal structure and biogenesis." Detected genes in the category "Energy production and conversion" included features involved in the respiratory chain (e.g., cytochrome c, cytochrome c oxidase subunit I, NADH dehydrogenase [ubiquinone]) and photosynthesis (e.g., fucoxanthin-chl $a-c$ binding proteins $\mathrm{B}$ and $\mathrm{E}$ ). Genes relevant for translation encoded ribosomal proteins. Concerning genes related to the cytoskeleton, genes encoding actin, an actin binding protein, profilin, gelsolin, and the beta chain of tubulin were found to be up-regulated (Table S1).

Down-regulated genes were allocated primarily to the categories "Translation, ribosomal structure and biogenesis," "Cytoskeleton," and "Energy production and conversion." The KOG category "Translation, ribosomal structure and biogenesis" was mainly comprised of ribosomal protein genes, which were different from the up-regulated genes assigned to this category. Genes allocated to the cytoskeleton category included only genes encoding actin, while the category "Energy production and conversion" contained primarily genes related to photosynthesis (e.g., oxygen-evolving enhancer protein 3, P700 apoprotein A1 of Photosystem I, fucoxanthin-chl $a-c$ binding protein, D2 reaction center protein of photosystem II, and photosystem II $4 \mathrm{kDa}$ reaction centre component; Table S1).

Patterns after $24 d$ of grazing: Genes that were upregulated in $F$. vesiculosus after $24 \mathrm{~d}$ of $L$. obtusata grazing mainly belonged to the categories "Translation, ribosomal structure and biogenesis," "Cytoskeleton," and "Energy production and conversion." Translation-related genes encoded the translation associated protein 7 and several ribosomal proteins. Features relevant for the cytoskeleton included actin, tubulin, profilin, and a formin homologue. Genes assigned to the category "Energy production and conversion" encoded proteins involved in the respiratory chain (e.g., cytochrome c, NADH dehydrogenase [ubiquinone] 1 beta subcomplex subunit 3) and a few photosynthesis-related proteins (e.g., fucoxanthin-chl $a-c$ binding protein E; Table S1).

Seventy-three per cent of all annotated genes that were down-regulated $24 \mathrm{~d}$ after the onset of grazing were assigned to the following two KOG categories: "Energy production and conversion" and "Translation, ribosomal structure and biogenesis." The category "Energy production and conversion" primarily included genes coding for photosynthesis-related genes, such as the D2 reaction center protein of photosystem II, P700 apoprotein A1 of Photosystem I, Photosystem II $4 \mathrm{kDa}$ reaction centre component, and the large subunit of ribulose-1,5-bisphosphate carboxylase/oxygenase. Genes involved in translation encoded ribosomal proteins and were different from the up-regulated genes assigned to this category (Table S1).

\section{DISCUSSION}

Consumption of $F$. vesiculosus pieces previously grazed by L. obtusata was significantly lower compared to controls at several times during the induction phase. Reduced palatability of previously grazed seaweed pieces was most likely caused by an induction of antiherbivory defenses, and not by the removal of all tasty tissue parts during the induction phase, since only $2.3 \%$ of algal tissue were consumed during this phase. Reconstituted food assays confirmed consumer preferences of assays using fresh $F$. vesiculosus. Since any morphological differences between previously grazed and ungrazed seaweed pieces were eliminated during the preparation of artificial food pellets, the induced antiherbivory defense seems to be of chemical nature. This interpretation corroborates results of previous studies testing for the induction of chemical defenses in F. vesiculosus (e.g., Rohde et al. 2004, Long et al. 2007, Rohde and Wahl 2008, Yun et al. 2007).

However, both types of feeding assays, i.e., assays with reconstituted food and fresh seaweed pieces, showed that defenses were switched on and off alternately in the course of the induction phase after their initial detection at $\mathrm{d} 9$ and 15 respectively (Fig. 3). These results corroborate a temporally variable defense in response to I. baltica grazing in $F$. vesiculosus (Flöthe et al. in press). Correspondingly, periwinkle consumption rates in induction aquaria showed a decline until day 15 when an induced defense was detected in feeding assays and a second decline after day 24 when defenses were again detected in feeding assays (Fig. 2 ). However, consumption of inducers did not vary significantly during the induction phase, possibly due to the fact that inducers were forced at all times to feed on $F$. vesiculosus pieces in the induction aquaria because there was no alternative choice. In contrast, periwinkles were allowed to choose between treated and control F. vesiculosus pieces in feeding assays and were able to feed on control pieces at times when previously grazed pieces were less palatable than controls. The observed variation in palatability of continuously periwinkle-grazed $F$. vesiculosus supports findings by Flöthe and Molis (2013) and Flöthe et al. (in press), who reported comparable dynamics in $L$. $o b$ tusata grazed A. nodosum and I. baltica-grazed F. vesiculosus. Temporal variation in the induction of antiherbivory responses is also known from terrestrial plants (e.g., Turlings et al. 1995) and may be favorable for different reasons. First, by using defense pulses grazers may be deterred at minimum cost (see Flöthe et al. in press). Second, temporal variation in palatability lowers the predictability of food quality, leading to increased feeding dispersal and reduced average meal sizes of herbivores (Borell et al. 2004). Hence, localized 
grazing and consequently the probability of waveinduced frond breakage at damaged thallus segments will be reduced. Third, dynamic defense responses may hamper physiological grazer adaptations and coevolution in seaweed-herbivore interactions (Gardner and Agrawal 2002).

Fresh food feeding assays revealed a prolongation of individual defense pulses after day 21. An extended defense pulse was not detectable in reconstituted food assays, indicating that additional morphological defense traits may have been induced after 3 weeks of L. obtusata grazing. Unfortunately, thallus toughness of grazed and ungrazed $F$. vesiculosus pieces was not measured in this study. However, herbivore consumption has previously been shown to be negatively correlated with tissue toughness (Pennings and Paul 1992, Chavanich and Harris 2002) and the combination of chemical and morphological defenses is a known strategy of coral reef seaweeds (Paul and Hay 1986, Hay et al. 1994). This strategy could be used also by temperate seaweeds like $F$. vesiculosus to ensure effective herbivore deterrence.

Seaweed-mediated indirect effects. Grazing by L. obtusata induced a defense response with low specificity, i.e., it decreased $F$. vesiculosus palatability for both consumer species. A reduction of previously L. obtusata grazed fresh and reconstituted $F$. vesiculosus for I. baltica indicates a seaweed-mediated indirect effect on isopod feeding. Thus, L. obtusata indirectly reduced energy intake of $I$. baltica from their shared resource and may be considered as the superior competitor. Long et al. (2007) experimentally documented a lower density of Littorina littorea on $L$. obtusata grazed than on ungrazed $F$. vesiculosus, suggesting that grazing by L. obtusata drives competitors away from the shared resource. However, results from fresh and reconstituted food feeding assays indicate that the differential palatability of $F$. vesiculosus and thus indirect competition between both grazer species may vary with time.

The temporal difference in the initial detection of antiherbivory defenses in feeding assays using I. baltica and L. obtusata (9 and $15 \mathrm{~d}$, respectively) may have arisen because L. obtusata is a feeding specialist and may have gained a greater tolerance to the induced defense of $F$. vesiculosus by co-evolutionary processes compared to the generalist I. baltica (Ali and Agrawal 2012). Furthermore, slow-moving periwinkles are subjected to induced defense responses for longer time spans compared to fastmoving isopods. This may have fostered a greater tolerance of $L$. obtusata against defenses induced in its prey (see also Duffy and Hay 1994). However, earlier deterrence of isopods compared with periwinkles was not apparent in feeding assays using reconstituted food. As shown by Nietsch (2009), thallus toughness and palatability to I. baltica are negatively correlated in $F$. vesiculosus, and I. baltica may have been deterred by induced morphological seaweed trait(s) at day 9 .
Interestingly, feeding assays revealed that L. obtusata and I. baltica showed slight differences with respect to the time points at which controls were preferred over previously grazed pieces, possibly due to different tolerance levels for defense metabolites. Sotka and Gantz (2013) showed that herbivore consumption rates in no-choice feeding assays were limited by seaweed extract intake rates. These results are in accordance with the detoxification limitation hypothesis (reviewed by Marsh et al. 2006) suggesting that the quantity of a plant eaten by an herbivore is largely dependent on the ability of the herbivore to eliminate the plant's secondary metabolites. This may also explain the slight differences in the timing of the defense pulses between fresh and reconstituted food feeding assays. A difference in the concentration of secondary metabolites between fresh seaweed pieces and artificial food pellets may have caused small discrepancies in the time at which the herbivore's tolerance limit was reached.

Gene expression patterns. Gene expression analysis was applied to elucidate cellular processes involved in the phenotypically plastic antiherbivory response of $F$. vesiculosus to $L$. obtusata grazing.

About 180 genes were differentially expressed in response to grazing 3,12 , and $24 \mathrm{~d}$ after onset of grazing, while approximately twice as many genes were up- or down-regulated after 15 and $21 \mathrm{~d}$. Although this study cannot provide information about gene regulation in the first hours following herbivore attack due to the timing of microarray analysis, the observed numbers of regulated genes suggest (i) a general grazing and/or stress response in place already $3 \mathrm{~d}$ after the onset of grazing, which is enhanced by (ii) an additional, more specific response that involves the regulation of more genes once defenses were first detected in feeding assays (day 15), and (iii) a return to the "basal stress level" in the late induction phase.

Grazing periwinkles often inflict severe wounds to algal fronds (Pavia and Toth 2000, Viejo and Ảberg 2003). Therefore, differential gene expression between previously grazed and nongrazed $F$. vesiculosus pieces may not be explained by the induction of antiherbivory traits alone, but also by the physical damage requiring tissue repair, which was, however, not investigated in this study.

In general, all points in time share a strong upand down-regulation of translation-associated proteins. The regulation of genes related to the basal metabolism has already been described for isopodgrazed F. vesiculosus (Flöthe et al. in press) and may indicate that increased protein synthesis, i.e., translation of already existing mRNA transcripts, plays an important role in defense induction.

Genes encoding proteins involved in photosynthesis were down-regulated within $3 \mathrm{~d}$ after herbivore attack and kept on a low level throughout the entire grazing period, i.e., also between single defense 
pulses. Although photosynthesis is the most important energy provider of photoautotrophs, photosynthetic processes are known to be inversely correlated with the induction of defense mechanisms (e.g., Bilgin et al. 2010, Flöthe et al. in press). Down-regulating photosynthesis may be advantageous for plants for several reasons. First, reduced investment in photosynthetic proteins may facilitate resource reallocation from primary to secondary metabolism. Second, oxidative damage by toxic oxygen derivatives generated by the photosynthetic electron transport chain may be minimized (Niyogi 2000). Third, the primary product of photosynthesis in $F$. vesiculosus is mannitol, which attracts isopods (Bidwell et al. 1972, Weinberger et al. 2011) and may also be a feeding cue for periwinkles. Down-regulation of photosynthesis may thus prevent the attraction of additional grazers and possibly also of the inducing herbivore L. obtusata.

In contrast, genes involved in energy generation via the respiratory chain were found to be up-regulated 15, 21, and $24 \mathrm{~d}$ after the onset of grazing. It has already been shown that isopod-grazed $F$. vesiculosus seems to use storage compounds to cover its increased requirements for energy, reducing equivalents, and precursors (Flöthe et al. in press). Therefore, the degradation of lipids and carbohydrates and generation of energy via the respiratory chain are likely to increase also in periwinkle-grazed $F$. vesiculosus, especially when photosynthesis is downregulated. The usage of reserves may be interpreted as a cost associated with the induction of antiherbivory defenses.

In addition, changes in gene expression indicating rearrangements of the cytoskeleton were found at almost all times. Phenolic compounds, such as phlorotannins, are important cell wall constituents in brown seaweeds and are furthermore suggested to have antifeeding activity. Phlorotannins are located inside the cells in vesicles, which are moved along cytoskeletal filaments and accumulate at wound sites within $3 \mathrm{~d}$ after wounding (Fagerberg and Dawes 1977, Schoenwaelder and Clayton 1999, Lüder and Clayton 2004). Also vesicles containing other secondary metabolites with defensive attributes may be transported via the cytoskeleton (e.g., Reis et al. 2013). Therefore, reorganization of the cytoskeleton throughout the induction phase may be related to the healing of wounds caused by continuous exposure to grazing and/or transport of defense metabolites.

A comparison of the two defense pulses (day 15 and 24) shows that the first, compared to the second pulse entailed a larger number of regulated genes. This difference may hint at a mechanism similar to priming, which was also found in the brown alga Laminaria digitata (Thomas et al. 2011). Priming may have occurred during the first defense pulse leading to a smaller number of regulated genes during the second defense pulse. Moreover, the two defense pulses shared about $50 \%$ of their regulated genes (Table $\mathrm{S} 1$ ). Some of these common genes were involved in energy production and conversion, translation, and the rearrangement of the cytoskeleton and may be considered as general stress response genes. Due to missing annotation data for the remaining genes, drawing conclusions about the processes that may be unique to one or another defense pulse and potential priming mechanisms is difficult.

Comparing changes in $\mathrm{F}$. vesiculosus gene expression induced by periwinkle and isopod grazing. When comparing transcriptional changes in response to $L$. $o b$ tusata and I. baltica grazing at points in time when palatability of previously grazed $F$. vesiculosus was significantly reduced relative to ungrazed controls, it becomes evident that to some extent both herbivore species elicit similar cellular processes in $F$. vesiculosus. These common processes include down-regulation of photosynthesis and up-regulation of genes related to the respiratory chain (Fig. 4). This similarity in grazing-induced cellular processes is reflected by $\sim 50$ commonly regulated genes (Fig. 4, Table S2 in the Supporting Information) and is corroborated by a low specificity of effect (i.e., damage by L. obtusata increases also resistance to I. baltica).

Many of these genes lack functional annotations so far. However, they are interesting candidates for further in-depth studies and should be examined for similar expression patterns in $F$. vesiculosus in response to grazing by other herbivore species and also in other seaweed species facing herbivore attack.

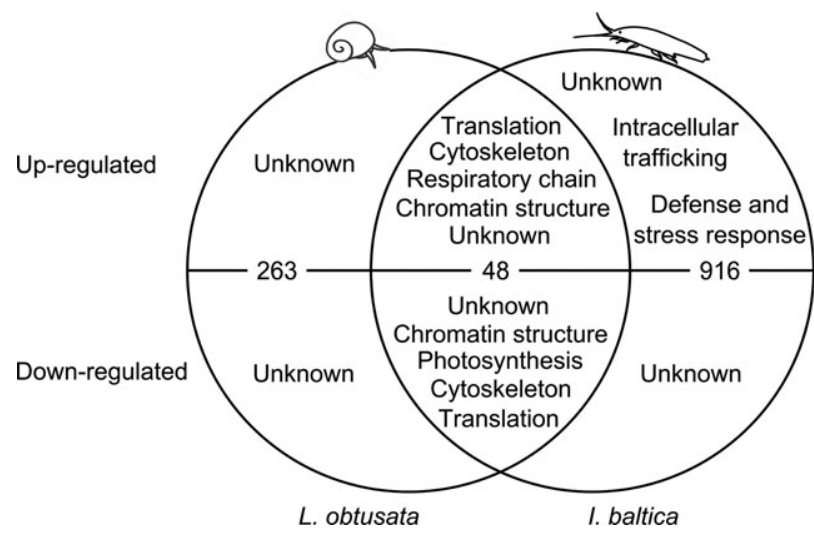

FIG. 4. Number of differentially expressed Fucus vesiculosus genes with $\mathrm{a} \geq 1.5$ or $\leq-1.5$ fold change and cellular processes underlying defense induction in response to grazing by Littorina obtusata and Idotea baltica. Overlap displays (1) the number of regulated genes and (2) common up- and down-regulated cellular processes which were induced in response to both herbivore species. Only genes that were differentially expressed between controls and previously grazed $F$. vesiculosus pieces at time points, when a reduced palatability of previously grazed pieces was detected in feeding assays (this study: 15 and $24 \mathrm{~d}$ after start of induction; Flöthe et al. in press: $18 \mathrm{~d}$ after onset of grazing), were considered. 
On the other hand, numerous genes were up- or down-regulated by only one of the two herbivore species. Herbivory is unavoidably accompanied by wounding. Vascular plants were shown to respond differently to wounding by herbivores representing different feeding modes (Walling 2000). Also some of the observed differences in gene expression between periwinkle (radula) and isopod (mandibles) grazed $F$. vesiculosus may be attributed to differences in mechanical damage. However, a study using the related brown alga A. nodosum did not find induction of antiherbivory traits in response to artificial damage alone (Pavia and Toth 2000, Borell et al. 2004), while defenses were induced by adding saliva components to artificially created wounds (Coleman et al. 2007). Likewise, grazing by several herbivore species induces a defense in $F$. vesiculosus, whereas mechanical damage does not (e.g., Rohde et al. 2004). Therefore, it can be assumed that additional herbivore-specific elicitors are involved in the induction of the antiherbivory response. Thus, differences in the gene regulation elicited by L. obtusat$a$ and I. baltica may be caused by differences in saliva and/or regurgitate composition (Coleman et al. 2007), microbial commensalists, pathogen vectoring or level of specialization (Ali and Agrawal 2012). Furthermore, as L. obtusata consumed less $F$. vesiculosus during the induction phase compared to I. baltica, differences in the gene regulation in response to periwinkle and isopod attack may have been caused or reinforced by the different grazing rates.

When comparing the transcriptional response of $F$. vesiculosus to both herbivores, it becomes apparent that (i) isopod feeding changed the expression of more than twice as many genes as periwinkle grazing and that (ii) only a very small number of putative defense-related genes were induced by periwinkle feeding (e.g., a gene encoding a papain-like cysteine protease, Table S1), while isopod feeding increased the expression of several defense-related genes (e.g., lipoxygenase, peroxidas 34, cytochrome $\mathrm{P} 450$ ) and to a much greater extent than periwinkle grazing (up to 12.2-fold up-regulation compared to controls). It may be suggested that adapted specialists (L. obtusata) may have evolved mechanisms to minimize or even suppress host defense gene expression, leading to a "weaker" and/or less diverse expression of defense-related genes (Reymond et al. 2004). In contrast, temporarily present generalist herbivores have to face diverse defense strategies of various seaweeds, complicating the evolution of mechanisms that weaken the antiherbivory responses of prey species (Reymond et al. 2004). Furthermore, inducible defense theory assumes that anti-herbivory responses will be induced when grazing pressure is high (Karban and Baldwin 1997). Thus, the four times lower amount of biomass removed by periwinkles during the induction phase (2.3\% of wet mass compared to $10.2 \%$ reduced by
I. baltica) may have induced a "weaker" response in F. vesiculosus. Although the transcriptional response to periwinkle and isopod damage differs to some extent, these responses may result in the production of the same defensive metabolites, which would explain the additional deterrence of isopods. In that case, the observed differences may result from changes in the expression of genes which (i) are not involved in the general stress-response (i.e., reprogramming of cellular functions, such as protein synthesis, photosynthesis and energy generation via the respiratory chain, or rearrangement of the cytoskeleton) and (ii) do not encode products that are directly involved in herbivore deterrence (e.g., toxins). Instead, they may encode signaling pathways specific to certain external stimuli (e.g. salivary components; Coleman et al. 2007) and, thus, different herbivore species (see also Gatehouse 2002).

\section{CONCLUSION}

This study suggests a precisely regulated response of $F$. vesiculosus to grazing which is characterized by a high level of temporal variation. As F. vesiculosus is a nonmodel species and whole-genome sequencing has not been conducted by now, limited annotation rates make it difficult to fully discover underlying cellular processes and to identify candidate genes relevant for the induction of antiherbivory defenses. However, common alterations of particular cellular processes in response to periwinkle and isopod grazing suggest that these processes, e.g., shut-down of photosynthesis and degradation of stored reserves to make resources available for secondary defense pathways, are integral parts of defense induction. On the other hand, differences in the transcriptional responses to periwinkle and isopod grazing may be explained by distinct signaling pathways elicited by herbivore-specific cues. Additional regulatory changes not occurring at the mRNA level (e.g., enzyme activation or protein biosynthesis) may complete the antiherbivory response to different herbivore species. As such changes cannot be detected with the microarray technology other techniques have to be integrated into the study of seaweed-herbivore interactions to perfect the understanding of cellular processes underlying the induction of antiherbivory defenses in $F$. vesiculosus.

We thank Monique Bartels for assistance in the laboratory and Simon Dittami for the language check of this manuscript. Financial support was provided by the PACES research program of the Alfred-Wegener-Institut Helmholtz-Zentrum für Polar- und Meeresforschung. CRF was financially supported by a fellowship from the Rosa Luxemburg Foundation.

Ali, J. G. \& Agrawal, A. A. 2012. Specialist versus generalist insect herbivores and plant defense. Trends Plant Sci. 17:293-302.

Apt, K. E., Clendennen, S. K., Powers, D. A. \& Grossman, A. R. 1995. The gene family encoding the fucoxanthin chlorophyll 
proteins from the brown alga Macrocystis pyrifera. Mol. Gen. Genet. 246:455-64.

Augner, M. 1995. Low nutritive quality as a plant defence: effects of herbivore-mediated interactions. Evol. Ecol. 9:605-16.

Bärlocher, F. 1999. Biostatistik. Thieme, Stuttgart, 206 pp.

Bidwell, R. G. S., Percival, E. \& Smestad, B. 1972. Photosynthesis and metabolism of marine algae. VIII. Incorporation of ${ }^{14} \mathrm{C}$ into the polysaccharides metabolized by Fucus vesiculosus during pulse labeling experiments. Can. J. Bot. 50:191-7.

Bilgin, D. D., Zavala, J. A., Zhu, J. I. N., Clough, S. J., Ort, D. R. \& DeLucia, E. H. 2010. Biotic stress globally downregulates photosynthesis genes. Plant, Cell Environ. 33:1597-613.

Borell, E., Foggo, A. \& Coleman, R. 2004. Induced resistance in intertidal macroalgae modifies feeding behaviour of herbivorous snails. Oecologia 140:328-34.

Chavanich, S. \& Harris, L. G. 2002. The influence of macroalgae on seasonal abundance and feeding preference of a subtidal snail, Lacuna vincta (Montagu) (Littorinidae) in the Gulf of Maine. J. Molluscan Stud. 68:73-8.

Cheong, Y. H., Chang, H. S., Gupta, R., Wang, X., Zhu, T. \& Luan, S. 2002. Transcriptional profiling reveals novel interactions between wounding, pathogen, abiotic stress, and hormonal responses in Arabidopsis. Plant Physiol. 129:661-77.

Coleman, R. A., Ramchunder, S. J., Moody, A. J. \& Foggo, A. 2007. An enzyme in snail saliva induces herbivore-resistance in a marine alga. Funct. Ecol. 21:101-6.

Cronin, G. \& Hay, M. 1996. Within-plant variation in seaweed palatability and chemical defenses: optimal defense theory versus the growth-differentiation balance hypothesis. Oecologia 105:361-8.

Deal, M. S., Hay, M. E., Wilson, D. \& Fenical, W. 2003. Galactolipids rather than phlorotannins as herbivore deterrents in the brown seaweed Fucus vesiculosus. Oecologia 136:107-14.

Duffy, J. E. \& Hay, M. E. 1990. Seaweed adaptations to herbivory. Bioscience 40:368-75.

Duffy, J. E. \& Hay, M. E. 1994. Herbivore resistance to seaweed chemical defense: the roles of mobility and predation risk. Ecology 75:1304-19.

Enge, A. 2006. Trophische interaktionen zwischen Laminaria digitata und mesoherbivoren. Diploma thesis, University of Rostock, Rostock, Germany, 87 pp.

Fagerberg, W. R. \& Dawes, C. J. 1977. Studies on Sargassum II. Quantitative ultrastructural changes in differentiated stipe cells during wound regeneration and regrowth. Protoplasma 92:211-27.

Flöthe, C. R. \& Molis, M. 2013. Temporal dynamics of inducible anti-herbivory defenses in the brown seaweed Ascophyllum nodosum (Phaeophyceae). J. Phycol. 49:468-74.

Flöthe, C. R., Molis, M., Kruse, I., Weinberger, F. \& John, U. in press. Herbivore-induced defence response in the brown seaweed Fucus vesiculosus (Phaeophyceae): temporal pattern and gene expression. Eur. J. Phycol.

Gaines, S. D. \& Lubchenco, J. 1982. A unified approach to marine plant-herbivore interactions. II. Biogeography. Annu. Rev. Ecol. Syst. 13:111-38.

Gardner, S. N. \& Agrawal, A. A. 2002. Induced plant defence and the evolution of counter-defences in herbivores. Evol. Ecol. Res. 4:1131-51.

Gatehouse, J. A. 2002. Plant resistance towards insect herbivores: a dynamic interaction. New Phytol. 156:145-69.

Geiselman, J. A. \& McConnell, O. J. 1981. Polyphenols in brown algae Fucus vesiculosus and Ascophyllum nodosum: chemical defenses against the marine herbivorous snail, Littorina littorea. J. Chem. Ecol. 7:1115-33.

Golléty, C., Riera, P. \& Davoult, D. 2010. Complexity of the food web structure of the Ascophyllum nodosum zone evidenced by a $\delta^{13} \mathrm{C}$ and $\delta^{15} \mathrm{~N}$ study. J. Sea Res. 64:304-12.

Hay, M. E. 1996. Marine chemical ecology: what's known and what's next? J. Exp. Mar. Biol. Ecol. 200:103-34.

Hay, M. E., Kappel, Q. E. \& Fenical, W. 1994. Synergisms in plant defenses against herbivores: interactions of chemistry, calcification, and plant quality. Ecology 75:1714-26.

Heinrich, S., Valentin, K., Frickenhaus, S., John, U. \& Wiencke, C. 2012. Transcriptomic analysis of acclimation to tempera- ture and light stress in Saccharina latissima (Phaeophyceae). PLoS ONE 7:e44342.

Hemmi, A., Honkanen, T. \& Jormalainen, V. 2004. Inducible resistance to herbivory in Fucus vesiculosus: duration, spreading and variation with nutrient availability. Mar. Ecol. Prog. Ser. 273:109-20.

Karban, R., Agrawal, A. A., Thaler, J. S. \& Adler, L. S. 1999. Induced plant responses and information content about risk of herbivory. Trends Ecol. Evol. 14:443-7.

Karban, R. \& Baldwin, I. T. 1997. Induced Responses to Herbivory. The University of Chicago Press, Chicago, Illinois, 319 pp.

Kubanek, J., Lester, S. E., Fenical, W. \& Hay, M. E. 2004. Ambiguous role of phlorotannins as chemical defenses in the brown alga Fucus vesiculosus. Mar. Ecol. Prog. Ser. 277:7993.

Long, J. D., Hamilton, R. S. \& Mitchell, J. L. 2007. Asymmetric competition via induced resistance: specialist herbivores indirectly suppress generalist preference and populations. Ecology $88: 1232-40$.

Lubchenco, J. \& Gaines, S. D. 1981. A unified approach to marine plant-herbivore interactions. I. Populations and communities. Annu. Rev. Ecol. Syst. 12:405-37.

Lüder, U. \& Clayton, M. 2004. Induction of phlorotannins in the brown macroalga Ecklonia radiata (Laminariales, Phaeophyta) in response to simulated herbivory - the first microscopic study. Planta 218:928-37.

Marsh, K. J., Wallis, I. R., Andrew, R. L. \& Foley, W. J. 2006. The detoxification limitation hypothesis: where did it come from and where is it going? J. Chem. Ecol. 32:1247-66.

Moran, M. D. 2003. Arguments for rejecting the sequential Bonferroni in ecological studies. Oikos 100:403-5.

Nietsch, B. 2009. Messung der Zähigkeit der Makroalge Fucus vesiculosus an verschiedenen Standorten und Untersuchung der Auswirkungen auf die trophische Interaktion. Diploma thesis, University of Kiel, Kiel, Germany.

Niyogi, K. K. 2000. Safety values for photosynthesis. Curr. Opin. Plant Biol. 3:455-60.

Paul, V. J. \& Hay, M. E. 1986. Seaweed susceptibility to herbivory: chemical and morphological correlates. Mar. Ecol. Prog. Ser. 33:255-64.

Pavia, H. \& Toth, G. B. 2000. Inducible chemical resistance to herbivory in the brown seaweed Ascophyllum nodosum. Ecology 81:3212-25.

Pearson, G., Lago-Leston, A., Valente, M. \& Serrão, E. 2006. Simple and rapid RNA extraction from freeze-dried tissue of brown algae and seagrasses. Eur. J. Phycol. 41:97-104.

Pennings, S. C. \& Paul, V. J. 1992. Effect of plant toughness, calcification, and chemistry on herbivory by Dolabella auricularia. Ecology 73:1606-19.

Poore, A. G., Campbell, A. H., Coleman, R. A., Edgar, G. J., Jormalainen, V., Reynolds, P. L., Sotka, E. E., Stachowicz, J. J., Taylor, R. B., Vanderklift, M. A. \& Duffy, J. E. 2012. Global patterns in the impact of marine herbivores on benthic primary producers. Ecol. Lett. 15:912-22.

Quinn, G. G. P. \& Keough, M. J. 2002. Experimental design and data analysis for biologists. Cambridge University Press, Cambridge, UK, $556 \mathrm{pp}$.

Reis, V. M., Oliveira, L. S., Passos, R. M. F., Viana, N. B., Mermelstein, C., Sant'Anna, C., Pereira, R. C., Paradas, W. C., Thompson, F. L., Amado-Filho, G. M. \& Salgado, L. T. 2013. Traffic of secondary metabolites to cell surface in the red alga Laurencia dendroidea depends on a two-step transport by the cytoskeleton. PLoS ONE 8:e63929.

Reymond, P., Bodenhausen, N., Van Poecke, R. M. P., Krishnamurthy, V., Dicke, M. \& Farmer, E. E. 2004. A conserved transcript pattern in response to a specialist and a generalist herbivore. Plant Cell 16:3132-47.

Roa, R. 1992. Design and analysis of multiple-choice feeding-preference experiments. Oecologia 89:509-15.

Roda, A. M. Y., Halitschke, R., Steppuhn, A. \& Baldwin, I. T. 2004. Individual variability in herbivore-specific elicitors from the plant's perspective. Mol. Ecol. 13:2421-33. 
Rohde, S., Molis, M. \& Wahl, M. 2004. Regulation of anti-herbivore defence by Fucus vesiculosus in response to various cues. J. Ecol. 92:1011-8.

Rohde, S. \& Wahl, M. 2008. Temporal dynamics of induced resistance in a marine macroalga: time lag of induction and reduction in Fucus vesiculosus. J. Exp. Mar. Biol. Ecol. 367:2279.

Schoenwaelder, M. \& Clayton, M. 1999. The role of the cytoskeleton in brown algal physode movement. Eur. J. Phycol. 34:223-9.

Sotka, E. E. \& Gantz, J. 2013. Preliminary evidence that the feeding rates of generalist marine herbivores are limited by detoxification rates. Chemoecology 23:1-8.

Strauss, S. Y., Rudgers, J. A., Lau, J. A. \& Irwin, R. E. 2002. Direct and ecological costs of resistance to herbivory. Trends Ecol. Evol. 17:278-85.

Thomas, F., Cosse, A., Goulitquer, S., Raimund, S., Morin, P., Valero, M., Leblanc, C. \& Potin, P. 2011. Waterborne signaling primes the expression of elicitor-induced genes and buffers the oxidative responses in the brown alga Laminaria digitata. PLoS ONE 6:e21475.

Toth, G. B. \& Pavia, H. 2007. Induced herbivore resistance in seaweeds: a meta-analysis. J. Ecol. 95:425-34.

Turlings, T. C., Loughrin, J. H., McCall, P. J., Röse, U. S., Lewis, W. J. \& Tumlinson, J. H. 1995. How caterpillar-damaged plants protect themselves by attracting parasitic wasps. Proc. Natl. Acad. Sci. USA 92:4169-74.

Viejo, R. M. \& Aberg, P. 2003. Temporal and spatial variation in the density of mobile epifauna and grazing damage on the seaweed Ascophyllum nodosum. Mar. Biol. 142:1229-41.

Walling, L. L. 2000. The myriad plant responses to herbivores. J. Plant Growth Regul. 19:195-216.

Watt, C. A. \& Scrosati, R. A. 2013. Bioengineer effects on understory species richness, diversity, and composition change along an environmental stress gradient: experimental and mensurative evidence. Estuar. Coast. Shelf Sci. 123:10-8.

Weinberger, F., Rohde, S., Oschmann, Y., Shahnaz, L., Dobretsov, S. \& Wahl, M. 2011. Effects of limitation stress and of disruptive stress on induced antigrazing defense in the bladder wrack Fucus vesiculosus. Mar. Ecol. Prog. Ser. 427:83-94.

Yun, H. Y., Cruz, J., Treitschke, M., Wahl, M. \& Molis, M. 2007. Testing for the induction of anti-herbivory defences in four Portuguese macroalgae by direct and water-borne cues of grazing amphipods. Helgoland Mar. Res. 61:203-209.

Yun, H. Y., Rohde, S., Linnane, K., Wahl, M. \& Molis, M. 2010. Seaweed-mediated indirect interaction between two species of meso-herbivores. Mar. Ecol. Prog. Ser. 408:47-53.

Zangerl, A. R., Arntz, A. M. \& Berenbaum, M. R. 1997. Physiological price of an induced chemical defense: photosynthesis, respiration, biosynthesis, and growth. Oecologia 109:433-41.

\section{Supporting Information}

Additional Supporting Information may be found in the online version of this article at the publisher's web site:

Figure S1. Number and direction of regulation of responsive Fucus vesiculosus genes with a $\geq 1.5$ or $\leq-1.5$ fold change $3,12,15,21$, and $24 \mathrm{~d}$ after the onset of grazing by Littorina obtusata. Differentially expressed genes were revealed by two-way ANOVA testing for interactions of treatment (control/grazed) and time. Overlaps display the numbers of genes regulated at multiple points in time. $\uparrow=$ up-regulated, $\downarrow=$ down-regulated.

Table S1. Complete list of Fucus vesiculosus genes that were differentially regulated between seaweed pieces previously grazed by Littorina obtusata for $3,12,15,21$, and $24 \mathrm{~d}$, and nongrazed control pieces. Positive numbers indicate an increase in the expression level in previously grazed $F$. vesiculosus pieces relative to controls, while negative numbers indicate a decrease in the expression level.

Table S2. List of Fucus vesiculosus genes that were commonly up- or down-regulated (fold change $\geq 1.5$ or $\leq-1.5$ ) in response grazing by Littorina obtusata and Idotea baltica at time points when a reduced palatability of previously grazed seaweed pieces compared to ungrazed controls was detected in two-choice feeding assays (this study: 15 and $24 \mathrm{~d}$ after start of induction; Flöthe et al. in press: $18 \mathrm{~d}$ after onset of grazing). Positive numbers indicate an increase in the expression level in previously grazed $F$. vesiculosus pieces relative to controls, while negative numbers indicate a decrease in the expression level. 